\title{
Expressive language of children with hearing impairment
}

\author{
Elsa Efrina1, Mega Iswari ${ }^{2}$, Fauzi Irwanto ${ }^{3}$ \\ ${ }^{123}$ Universitas Negeri Padang, Padang - Indonesia, (elsaefrina@fip.unp.ac.id)
}

\begin{abstract}
Language is an important aspect of communication. The success in communication is determined by the language ability, including the expressive language. Children with hearing impairment have obstacles to conduct expressive language due to the lack of auditory experience. Thus, maternal reflective method can be used to improve the expressive language ability. This method is applied in a structured natural conversation by presenting the language fairly through conversation, visualization, deposit and reflection in order to retrieve the linguistic aspects. The findings showed that the method was effective for improving the ability of expressive language. This research was conducted by the pre-test and post-test values using the Mann Whitney $\mathrm{U}$ test, it was obtained that $\mathrm{U}=6$ and $\mathrm{Utab}=2$ with $\mathrm{n}=5$ at a significant level of $95 \%$ and $\alpha=0.05$. As $\mathrm{U}$ was higher than Utab, the alternative hypothesis was accepted.
\end{abstract}

Keywords: Expressive language, maternal reflective method, children with hearing impairment

\section{Introduction}

Language is pivotal tool in communication which enables people to convey their thought, identify their statements in order to solve their problems (Bunawan \& Yuwati, 2000). Generally, the language skill is developed by the experience by the stages of age. Usually, the process began when an infant starts to recognize the sign language from his environment which later is developed by his ability in comprehending the acquired symbols and the verbal of sign language. Thus, the process will lead the child to speak (expressive language). As the child grows up, he will develop visual receptive language (writing) and other receptive languages (one of them is reading) (Bunawan \& Yuwati, 2000).

Language skill is categorized into two; receptive and expressive language. Receptive language is the passive ability to understand ideas, feelings and the awareness of someone's intention which began to emerge at the age of eight months. Meanwhile expressive language is the active ability to convey the ideas, feelings and intentions to others which began to emerge at the age of one and this is the final stage in the language development (Gunawan, 2016).

The language development of a child is influenced by several factors, one of them is hearing. In the process of acquiring language, a child is not taught about a word and its meaning but to correlate between the experience and sign language through his hearing. When the child understands the 
relation between the sign and the object or the event he encountered, he forms a receptive language. And when the child expresses the ideas and his intentions through words, it is the first stage of expressive language development. The whole process is supported by the hearing ability (Bunawan \& Yuwati, 2000).

Hearing loss is divided into two; deaf and hard of hearing. Deaf refers to a severe hearing loss which is indicated by the difficulty in processing auditory information even with the help of auditory device. On the other hand, hard of hearing refers to a hearing loss where there may be enough residual hearing to catch process and acquire the language with or without auditory device (Hallahan \& Kauffman, 2006; Moores, 2001). The individual with hearing impairment caused by the damage of auditory organ will not acquire stimulation especially auditory stimulation.

A child with hearing impairment has trouble in identifying and connecting the symbols and the verbal signs of language. The language development of hearing impaired children is almost similar to normal kids, the difference is found in the acquisition of visual signs in everyday life that is not by the sound but the facial expression or hand gesture. Therefore, the expressive language is shown by facial expression, body and hand gestures as employed in sign language. The poor expressive language ability of the hearing impaired children may cause bad impact to his social life. Thus, in order to develop the language ability, there should be a method applied for them.

The research was conducted in the Special-Needs School (SLB) Wacana Asih Padang, where five children with hearing impairment were having difficulties in expressing language. When the writer was having conversation with the children, they had the tendency to ask (the question is uttered in spoken and sign language): "what is it called in the word or sentence?", when they tried to tell their experience. This shows their language ability to express their ideas is not developed normally.

One of the methods related to language development process is maternal reflective method. This is applied by structured natural conversation, visualized into written conversation upon the board, creating deposit to make the children realize about the language aspect and reflection. For this reason, the method has brought the motto 'say what you want to say'. From this point, the writer examined whether the expressive language ability of hearing impaired children can be developed by implementing maternal reflective method.

In this research, the expressive language ability means the ability of hearing impaired children in expressing their ideas and feeling throughout spoken language. The assessment aspect is the act of expressing by using the sentence with the correct structure, while the maternal reflective method is a method used by natural conversation activities applying the sentence in the correct structure and Enhanced Indonesian Spelling System (EYD).

Maternal reflective method is a method used in the language mastery for hearing impaired children by combining the best aspects of natural and structural method, which emphasizes in conversation and self-inventory of the language forms (Uden as cited in Bunawan \& Yuwati, 2000). The implementation of maternal reflective method is classified into several stages, namely conversation, visualization, deposit and reflection. Conversation means a spontaneous and natural daily conversation. Teachers use grab and double roles method as the dialogue partner. They direct, elaborate and utter children's expression into the correct word or sentence. Visualization is a supporting activity to comprehend the words emerged in conversation which is employed by gestures, signs and spoken or written forms. Deposit is a perusal making by using vocabularies appeared in the conversation and arranged in accordance with the material and curriculum. Reflection is a review of acquired language by conversing or reading which eventually make the children find the language system themselves. 


\section{Method}

This research was conducted by experimental method with one group pre-test and post-test design, refers to a method conducted upon a single group participants without a control group. The expressive language ability of hearing impaired children was examined twice, in the pre-test (the ability before the treatment) and post-test (the ability after the treatment). Intervention given to the subjects was maternal reflective method and the results of both tests were analyzed by Mann Whitney U test (Sugiyono, 2015) by using formula below:

$$
\begin{aligned}
& \mathrm{U}_{1}=\mathrm{n}_{1} \cdot \mathrm{n}_{2}+\frac{\mathrm{n}_{2}\left(\mathrm{n}_{2}+1\right)}{2}-\sum \mathrm{R}_{2} \\
& \mathrm{U}_{2}=\mathrm{n}_{1} \cdot \mathrm{n}_{2}+\frac{\mathrm{n}_{1}\left(\mathrm{n}_{1}+1\right)}{2}-\sum \mathrm{R}_{1}
\end{aligned}
$$

The data were collected by spoken test (pre-test and post-test). The language ability was assessed by several categories; the amount of the words, the words and sentence group and the sentences uttered by the children. The test had a total of 20 items with the maximum score of 40 . The assessment criteria were; able (B) for a score of 2, able with assistance (BDB) for a score of 1 and unable (TB) for a score of 0 .

The subjects of the research were five students of Grade 8 at Special-Needs School (SLB) Wacana Asih Padang. The subjects were chosen based on several criteria; they were students with the same obstacle (hearing impairment), students with similar expressive language ability and students with the same grade. The consideration in choosing the same grade is appropriate with the principle of the maternal reflective method conducted in classical setting.

\section{Results and Discussion}

The pre-test and post-test results can be seen in the table 1:

Table 1. <pre-test and post-test value>

\begin{tabular}{cccccc}
\hline No & Subject & Pre-test score & Post-test score & $\mathbf{R}_{\mathbf{1}}$ & $\mathbf{R}_{\mathbf{2}}$ \\
1 & A & 25 & 34 & 4 & 1 \\
2 & B & 17 & 29 & 7 & 2 \\
3 & C & 19 & 28 & 5 & 3 \\
4 & D & 6 & 13 & 10 & 8 \\
5 & E & 11 & 18 & 9 & 6 \\
& & 78 & 122 & 35 & 20 \\
\hline
\end{tabular}

Table 1 shows that the scores acquired are 78 in pre-test and 122 in post-test. Furthermore, the data is examined by Mann Whitney $U$ test resulting in $U 1=20$ and $U 2=5$. $U$ value (5) is compared with $U$ table (2) at significant level of $95 \%$ and $\alpha=0,05$, thus $U$ value $>U$ table. Therefore, the alternative hypothesis is accepted which means the maternal reflective method can be applied towards children with hearing impairment to improve their expressive language ability.

The findings of pre-test and post-test conducted by Whitney Mann $U$ test show the increase in children's expressive language ability after treated by maternal reflective method. On the other hand, before the treatment is given, the verbal expressions are only engaged with the familiar word utterance at their home, for instance; chicken, fish, spinach, cabbage, banana and apple, which means that the utterance are only limited in some nouns and common adjectives (angry, hate and sad). Instead of using adjectives (good, bad and naughty) in utterance of words group, children are rather 
too focused on the sentence structured by Subject (S) - Predicate (P) such as 'I eat' and Subject (S) Predicate $(\mathrm{P})$ - Object $(\mathrm{O})$ such as 'I ride motorcycle' and sometimes in the wrong order. After the children are treated, they are able to express the new words used in daily activities; such as the utterance of adjectives (jealous, gay and lesbian), nouns (trolley, ATM, and balance), verb (paddle), words grouping (ride motorcycle, go to the market and the structure has changed into Subject (S)Predicate (P)-Object (O)-Adverb (K) such as 'Hana and Friska go to the Transmart to buy some fruits'. Such improvement accords with Winarsih (2007) and Sadjaah (2005) who argue that maternal reflective method can stimulate the language ability of hearing impaired children through natural conversation in conveying the ideas and feelings.

\section{Conclusions}

Based on the findings of data analysis, it is concluded that the expressive language ability of hearing impaired children can be developed by the implementation of maternal reflective method. Teachers are suggested to apply the method to improve the expressive language ability of hearing impaired children in order to decrease the rift from the other kids with normal hearing.

\section{Acknowledgments}

This article was written based on the research conducted by the writer, hoping to be beneficial and referential for the readers and become an alternative method for teaching the children with hearing impairment.

\section{References}

Bunawan, L., \& Yuwati, C.S. (2000). Penguasaan Bahasa Anak Tunarungu. Jakarta: Santi Rama Gunawan, D. (2016). Modul Guru Pembelajar SLB Tunarungu. Bandung: PPPPTK dan PLB Hallahan, D. P. \& Kauffman, J. M. (2006). Exceptional Learners. Boston: Pearson Moores, D. F. (2001). Educating the Deaf. Boston: Hougton Mifflin Company Sadjaah, E. (2005). Pendidikan Bahasa bagi Anak Gangguan Pendengaran dalam Keluarga. Jakarta: Direktorat Pembinaan Pendidikan Tenaga Kependidikan dan Ketenagaan Perguruan Tinggi Sugiyono. (2015). Statistik Nonparametrik untuk Penelitian. Bandung: Alfabeta Winarsih, M. (2007). Intervensi Dini bagi Anak Tunarungu dalam Memperoleh Bahasa. Jakarta: Direktorat Pembinaan Pendidikan Tenaga Kependidikan dan Ketenagaan Perguruan Tinggi 